\title{
PCR Primers To Amplify 16S rRNA Genes from Cyanobacteria
}

\author{
ULRICH NÜBEL, FERRAN GARCIA-PICHEL, AND GERARD MUYZER* \\ Max Planck Institute for Marine Microbiology, D-28359 Bremen, Germany
}

Received 26 February 1997/Accepted 20 May 1997

\begin{abstract}
We developed and tested a set of oligonucleotide primers for the specific amplification of 16S rRNA gene segments from cyanobacteria and plastids by PCR. PCR products were recovered from all cultures of cyanobacteria and diatoms that were checked but not from other bacteria and archaea. Gene segments selectively retrieved from cyanobacteria and diatoms in unialgal but nonaxenic cultures and from cyanobionts in lichens could be directly sequenced. In the context of growing sequence databases, this procedure allows rapid and phylogenetically meaningful identification without pure cultures or molecular cloning. We demonstrate the use of this specific PCR in combination with denaturing gradient gel electrophoresis to probe the diversity of oxygenic phototrophic microorganisms in cultures, lichens, and complex microbial communities.
\end{abstract}

To understand the ecology of cyanobacteria, it is desirable to match isolated strains and their counterparts in nature. Only then can physiological data gained from culture studies begin to be confidently extrapolated to natural conditions $(9,16)$. Inadequate culture conditions leading to the loss of various morphological characteristics (9), researchers' inability to grow certain organisms in the laboratory $(12,43)$, and misidentifications of strains in culture collections $(16,47)$ make it difficult in many cases to apply taxonomic assignments based on cultures to field populations. Both classification systems for the cyanobacteria - the bacteriological approach $(9,20,34)$ as well as the traditional botanical approach $(2,17)$-rely primarily on morphological characteristics of cells and colonies and do not necessarily lead to the identification of phylogenetically coherent taxa $(10,45)$. At all taxonomic levels above species, the sequence analysis of genes encoding small-subunit ribosomal RNA (16S rRNA) is currently the most promising approach for the phylogenetic classification of cyanobacteria (47). Furthermore, the comparative analysis of $16 \mathrm{~S}$ rRNA gene sequences provides a new means to investigate the discrepancy between strain collections and natural communities $(11,44)$. Sequences of $16 \mathrm{~S}$ rRNA genes are independent from cultivation or growth conditions and can be retrieved by PCR from small amounts of DNA extracted from laboratory cultures or natural environments (18). Several different approaches to extend the analysis of $16 \mathrm{~S}$ rRNA from cyanobacteria beyond axenic cultures have been described. These approaches include antibiotic treatments to suppress heterotrophic bacteria in nonaxenic cultures (46), physical cleaning of cyanobacteria by micromanipulation (16), and molecular cloning followed by screening for plasmid inserts of interest $(29,44)$.

On the basis of published 16S rRNA sequences, we developed a PCR procedure for the selective retrieval of cyanobacterial rRNA gene fragments from a variety of natural and artificial settings. The combination of this procedure with denaturing gradient gel electrophoresis (DGGE), a technique for the sequence-dependent separation of DNA molecules (19, 23 ), proved useful to visualize the diversity of cyanobacterial $16 \mathrm{~S}$ rRNA genes in environmental samples, to detect the uniqueness of isolated strains, and to assign PCR products

\footnotetext{
* Corresponding author. Mailing address: Max Planck Institute for Marine Microbiology, Celsiusstr. 1, D-28359 Bremen, Germany. Phone: 49-421-2028-934. Fax: 49-421-2028-690. E-mail: gerard@post gate.mpi-mm.uni-bremen.de.
}

derived from cultures to populations in the field. PCR products containing a single homogeneous population of DNA molecules are recognized as single bands after DGGE and can be directly sequenced, yielding information about approximately 700 nucleotides of the 16S rRNA genes. Sequence data, therefore, can be generated without time-consuming molecular cloning procedures from cyanobacterial cultures containing heterotrophic bacteria, allowing the rapid survey of a collection of strains for genetic diversity.

Specificity of PCR. Primer design was based on an alignment of all 16S rRNA sequences from cyanobacteria available from the Ribosomal Database Project (22) and GenBank (4). Primer sequences and target regions within the 16S rRNA gene are listed in Table 1. The forward primers CYA106F and CYA359F were used alternatively, whereas the reverse primer, referred to hereafter as CYA781R, was an equimolar mixture of CYA781R(a) and CYA781R(b). Forty-nucleotide GC-rich sequences at the $5^{\prime}$ end of the forward primers improved the detection of sequence variations in the amplified DNA fragments in subsequent DGGE (37). The primers were synthesized commercially (Biometra, Göttingen, Germany).

Primer specificities with reference to published sequences were checked with the CHECK_PROBE program supported by the Ribosomal Database Project and the BLAST program (1) at the National Center for Biotechnology Information, Washington, D.C. The primers CYA359F and CYA781R match virtually all 174 16S rRNA sequences from cyanobacteria currently deposited in public databases as of June 1997. There is evidence that the apparent mismatches in the few exceptions correspond to sequencing errors for one or more of the following reasons. The nonmatching nucleotides (i) would disrupt the secondary structures of the corresponding RNA molecules, (ii) affect positions considered to be invariant among prokaryotic $16 \mathrm{~S}$ rRNA sequences (41), and (iii) simply are contradictory to sequences determined for the same strains by other researchers. In contrast, CYA106F has one to three mismatches to $16 \mathrm{~S}$ rRNA genes from many strains of cyanobacteria affiliated with various phylogenetic groups. Therefore, this primer is not recommended for the analysis of microbial community composition. However, in this study it was successfully used in combination with CYA781R to specifically generate amplification products from cyanobacteria and diatom plastids from axenic and nonaxenic unialgal cultures (Table 2).

Plastids are believed to be an early offshoot of the cyanobacterial evolutionary line (28). Probably after a single primary 
TABLE 1. Primer sequences and target sites

\begin{tabular}{llcr}
\hline \multicolumn{1}{c}{ Primer $^{a}$} & \multicolumn{5}{c}{ Sequence $\left(5^{\prime}\right.$ to $\left.3^{\prime}\right)$} & Target site $^{b}$ \\
\hline CYA106F $^{c}$ & CGG ACG GGT GAG TAA CGC GTG A & $106-127$ \\
CYA359F & GGG GAA TYT TCC GCA ATG GG & $359-378$ \\
CYA781R(a) & GAC TAC TGG GGT ATC TAA TCC CAT T & $781-805$ \\
CYA781R(b) & GAC TAC AGG GGT ATC TAA TCC CTT T & $781-805$ \\
\hline
\end{tabular}

${ }^{a} \mathrm{R}$ (reverse) and $\mathrm{F}$ (forward) designations refer to primer orientation in relation to the rRNA. A 40-nucleotide GC-rich sequence (5'-CGC CCG CCG CGC CCC GCG CCG GTC CCG CCG CCC CCG CCC G-3') is attached to the $5^{\prime}$ end of the forward primers.

${ }^{b}$ E. coli numbering of $16 \mathrm{~S}$ rRNA nucleotides (7).

${ }^{c}$ Forward primers CYA106F and CYA359F were used in alternative reactions.

${ }^{d} \mathrm{Y}$, a $\mathrm{C} / \mathrm{T}$ nucleotide degeneracy.

${ }^{e}$ Reverse primer CYA781R was an equimolar mixture of CYA781R(a) and CYA781R(b).

endosymbiotic event, a nearly simultaneous radiation of the ancestors of recent cyanelles, rhodoplasts, and chloroplasts occurred and, subsequently, other plastids evolved through multiple secondary endosymbioses (6). Published 16S rRNA sequences from cyanelles match primers CYA106F, CYA359F, and CYA781F. Among the other two main plastid lineages, there are $16 \mathrm{~S}$ rRNA sequences with one or more mismatches to the sequences of cyanobacterial primers. On the basis of the limited data set currently available, a more detailed evaluation of primer specificity for phylogenetic groups of plastids is not yet possible. Therefore, the applicability of the PCR reported here for the analysis of eukaryotic phototrophs must await the advent of new $16 \mathrm{~S}$ rRNA sequences from plastids.

All primers presented here have sequences that match some $16 \mathrm{~S}$ rRNA sequences from bacteria not affiliated with the phylum of cyanobacteria. However, none of these sequences has fewer than two mismatches total to CYA359F and CYA781R. Thus, the combined use of both primers results in a PCR highly specific for cyanobacteria. CYA359F matches the 16S rRNA sequences from a number of gram-positive bacteria with a low $\mathrm{G}+\mathrm{C}$ content of the genomic DNA, namely Heliobacterium spp., several anaerobic halophiles, and relatives of Desulfotomaculum and Syntrophomonas. Information about the target site for reverse priming is also available for all these strains; most of them have four and some have two mismatches to CYA781R. An example of the latter is Pectinatus frisingensis DSM $6306^{\mathrm{T}}$, which we included in the experimental study of PCR specificity for this reason (Table 2). It could be safely discriminated against when PCR conditions were used as described below. On the other hand, CYA781R is complementary to the $16 \mathrm{~S}$ rRNAs from several crenarchaeota affiliated with the order Sulfolobales. However, these rRNA sequences have either ten or seven mismatches to CYA359F. Sulfolobus shibatae DSM $5389^{\mathrm{T}}$ (seven mismatches to CYA359F) was also included in the experimental study of PCR specificity (Table 2). The alternative forward primer CYA106F matches a number of published 16S rRNA sequences from prokaryotes with various phylogenetic affiliations outside the phylum of the cyanobacteria, not all of which contain information about the target site for reverse priming. Therefore, and in addition to the reasons discussed above, its applicability is limited, and it should not be used for studies on environmental nucleic acids of unknown composition. Yet, it has been included in the present report because it proved useful in the generation of sequence data from unialgal cultures. In these cases, the amplification specificity was checked by DGGE to investigate the sequence homogeneity of PCR products prior to sequence analysis. Despite its limitations, CYA106F might be preferred, because compared to CYA359F, its use generates longer amplification products (approximately 700 base pairs instead of
450), therefore enabling the determination of more informative sequence data.

PCR amplifications were performed with a Cyclogene Temperature Cycler (Techne, Cambridge, United Kingdom). Fifty picomoles of each primer, $25 \mathrm{nmol}$ of each deoxynucleoside triphosphate, $200 \mu \mathrm{g}$ of bovine serum albumin (35), $10 \mu \mathrm{l}$ of $10 \times$ PCR buffer (100 mM Tris-HCl [pH 9.0], $15 \mathrm{mM} \mathrm{MgCl}$, $500 \mathrm{mM} \mathrm{KCl}, 1 \%$ [vol/vol] Triton X-100, 0.1\% [wt/vol] gelatin), and $10 \mathrm{ng}$ of template DNA were combined with $\mathrm{H}_{2} \mathrm{O}$ to a volume of $100 \mu \mathrm{l}$ in a $0.5-\mathrm{ml}$ test tube and overlaid with 2 drops of mineral oil (Sigma Chemical Co., Ltd.). To minimize nonspecific annealing of the primers to nontarget DNA, $0.5 \mathrm{U}$ of SuperTaq DNA polymerase (HT Biotechnology, Ltd., Cambridge, United Kingdom) was added to the reaction mixture after the initial denaturation step $\left(5 \mathrm{~min}\right.$ at $\left.94^{\circ} \mathrm{C}\right)$, at $80^{\circ} \mathrm{C}$. Thirty-five incubation cycles followed, each consisting of $1 \mathrm{~min}$ at $94^{\circ} \mathrm{C}, 1 \mathrm{~min}$ at $60^{\circ} \mathrm{C}$, and $1 \mathrm{~min}$ at $72^{\circ} \mathrm{C}$. The annealing temperature for PCR was optimized empirically by the performance of PCRs with a nondegenerate reverse primer [50 pmol/100 $\mu$ l of CYA781R(a) instead of an equimolar mixture of CYA781R(a) and CYA781R(b)] and with amplification products of the complete 16S rRNA genes (24) from various cyanobacteria with known sequences as templates. With an annealing temperature of $60^{\circ} \mathrm{C}$, no amplification product was generated from templates with two mismatches to the reverse primer, as determined by agarose gel electrophoresis. When the degenerate reverse primer was applied in combination with either one of the forward primers, gene fragments from chromosomal DNAs were amplified from all cyanobacteria checked, spanning a broad range of cyanobacterial phylogeny, as is currently established, whereas other bacteria and archaea (Table 2) were discriminated against.

Nonaxenic cultures. The purification of cyanobacteria can be a difficult and time-consuming procedure, and often they are cultivated more easily when accompanied by heterotrophic bacteria $(9,13)$. Therefore, some strains growing as unicyanobacterial but nonaxenic cultures have been included in the bacteriological classification system (9). If conventional primers are used, targeting highly conserved regions of $16 \mathrm{~S}$ rRNA genes, PCR yields a heterogeneous mixture of amplification products from such cultures (Fig. 1C, lane 6), the direct sequence analysis of which is not possible. Prior to sequence determination, different DNA molecules need to be separated by cloning and the clone library has to be screened for the plasmid inserts of interest by multiple partial sequencing reactions (29). In contrast, the PCR reported here has been used to amplify cyanobacterial 16S rRNA gene fragments exclusively (nucleotide positions 106 to 805; Escherichia coli numbering system [7]) and thereby retrieve them from impure cultures. Twenty to one hundred micrograms of cells from cultures of 
TABLE 2. Strains used in this study

\begin{tabular}{|c|c|c|c|c|}
\hline Strain & Taxonomy or phylogeny ${ }^{a}$ & Source $^{b}$ & Axenic culture $^{c}$ & Amplification $^{d}$ \\
\hline \multicolumn{5}{|l|}{ Cyanobacteria } \\
\hline Cyanothece strain PCC 7418 & Chroococcales & PCC & + & + \\
\hline Cyanothece strain PCC 7424 & Chroococcales & PCC & + & + \\
\hline Synechococcus leopoliensis SAG 1402-1 & Chroococcales & SAG & + & + \\
\hline Dactylococcopsis strain PCC 8305 & Chroococcales & PCC & + & + \\
\hline Cyanothece strain MPI 95AH10 & Chroococcales & MPI & + & + \\
\hline Cyanothece strain MPI 95AH13 & Chroococcales & MPI & - & + \\
\hline Cyanothece strain MPI 96P402 & Chroococcales & MPI & - & + \\
\hline Aphanothece halophytica ATCC 43922 & Chroococcales & ATCC & - & + \\
\hline Synechococcus strain CI & Chroococcales & Y.C. & + & + \\
\hline Gloeocapsa strain C-90-Cal-G. (2) & Chroococcales & MPI & - & + \\
\hline Gloeothece sp. strain HW-91-Gth. (2) & Chroococcales & MPI & - & + \\
\hline Gloeothece rupestris SAG 36.87 & Chroococcales & SAG & - & + \\
\hline Lyngbya strain PCC 7419 & Oscillatoriales & PCC & + & + \\
\hline Microcoleus chthonoplastes MPI-NDN-1 & Oscillatoriales & MPI & - & + \\
\hline Geitlerinema strain PCC 9452 (10 mfx) & Oscillatoriales & MPI & - & + \\
\hline Geitlerinema strain SAG 3192 & Oscillatoriales & SAG & - & + \\
\hline Oscillatoria strain MPI 95OS01 & Oscillatoriales & MPI & - & + \\
\hline "Oscillatoria limnetica" & Oscillatoriales & Y.C. & - & + \\
\hline Spirulina strain MPI 95SS01 & Oscillatoriales & MPI & - & + \\
\hline Spirulina strain MPI 95SL01 & Oscillatoriales & MPI & - & + \\
\hline Scytonema strain B-77-Scy.jav. & Nostocales & MPI & - & + \\
\hline Calothrix strain Y-89-Cpwt.03 & Nostocales & MPI & - & + \\
\hline Aphanizomenon flos-aquae CCAP 1401/1 & Nostocales & P.K.H. & - & + \\
\hline \multicolumn{5}{|l|}{ Plastids } \\
\hline Amphora delicatissima MPI 96P201 & Bacillariophyceae (diatom) & MPI & - & + \\
\hline Navicula salinicola MPI 96P205 & Bacillariophyceae (diatom) & MPI & - & + \\
\hline \multicolumn{5}{|l|}{ Other bacteria } \\
\hline Paracoccus denitrificans DSM 65 & Proteobacteria, $\alpha$ subdivision & DSMZ & + & - \\
\hline Agrobacterium tumefaciens DSM 30205 & Proteobacteria, $\alpha$ subdivision & DSMZ & + & - \\
\hline Comamonas testosteroni DSM 50244 & Proteobacteria, $\beta$ subdivision & DSMZ & + & - \\
\hline Escherichia coli DSM 489 & Proteobacteria, $\gamma$ subdivision & DSMZ & + & - \\
\hline Thiomicrospira sp. strain MA 2-6 & Proteobacteria, $\gamma$ subdivision & H.J. & + & - \\
\hline Desulfobacterium vacuolatum & Proteobacteria, $\delta$ subdivision & DSMZ & + & - \\
\hline Clostridium acetobutylicum DSM 792 & Gram positive, low $\mathrm{G}+\mathrm{C}$ & DSMZ & + & - \\
\hline Paenibacillus polymyxa DSM 36 & Gram positive, low $\mathrm{G}+\mathrm{C}$ & DSMZ & + & - \\
\hline Pectinatus frisingensis DSM $6306^{\mathrm{T}}$ & Gram positive, low $\mathrm{G}+\mathrm{C}$ & DSMZ & + & - \\
\hline Rhodococcus rhodochrous DSM 43241 & Gram positive, high $\mathrm{G}+\mathrm{C}$ & DSMZ & + & - \\
\hline Cytophaga johnsonae DSM 2064 & Cytophaga group & DSMZ & + & - \\
\hline \multicolumn{5}{|l|}{ Archaea } \\
\hline Sulfolobus shibatae DSM $5389^{\mathrm{T}}$ & Sulfolobales & DSMZ & + & - \\
\hline
\end{tabular}

${ }^{a}$ Taxonomic affiliations of cyanobacteria sensu stricto Castenholz and Waterbury (9).

${ }^{b}$ Culture collections: ATCC, American Type Culture Collection, Rockville, Md.; CCAP, Culture Collection of Algae and Protozoa, Ambleside, United Kingdom; DSMZ, Deutsche Sammlung von Mikroorganismen und Zellkulturen, Braunschweig, Germany; H.J., H. Jannasch, Woods Hole Oceanographic Institution, Woods Hole, Mass.; MPI, Max Planck Institute for Marine Microbiology, Bremen, Germany; P.K.H., P. K. Hayes, University of Bristol, United Kingdom; PCC, Pasteur Culture Collection, Paris, France; SAG, Sammlung von Algenkulturen, Göttingen, Germany; Y.C., Y. Cohen, University of Jerusalem, Jerusalem, Israel.

${ }^{c}+$, axenic culture; - , nonaxenic culture.

${ }^{d}$ Amplification products yielded with both primer combinations CYA106F/CYA781R and CYA359F/CYA781R.

cyanobacteria was lysed by three sequential freezing (in liquid $\mathrm{N}_{2}$ ) and thawing (at $65^{\circ} \mathrm{C}$ ) steps followed by incubation for 20 $\mathrm{min}$ at $50^{\circ} \mathrm{C}$ in $5 \mathrm{ml}$ of TESC buffer $(100 \mathrm{mM}$ Tris- $\mathrm{HCl}$ [pH 8], $100 \mathrm{mM}$ EDTA, $1.5 \mathrm{M} \mathrm{NaCl}, 1 \%$ [wt/vol] hexadecylmethylammonium bromide) containing proteinase $\mathrm{K}$ at $100 \mu \mathrm{g} / \mathrm{ml}$ and $1 \%$ (wt/vol) sodium dodecyl sulfate. Chromosomal DNAs were extracted by applying phenol, chloroform, and isoamylalcohol (48) before they were used as templates in PCR. DGGE was performed as described previously (25), with the following modifications: 1-mm-thick polyacrylamide gels with a denaturant gradient from 20 to $60 \%$ were used, and electrophoresis was run in $1 \times$ TAE ( $40 \mathrm{mM}$ Tris- $\mathrm{HCl}$ [pH 8.3], $20 \mathrm{mM}$ acetic acid, $1 \mathrm{mM}$ EDTA) for $3.5 \mathrm{~h}$ at $200 \mathrm{~V}$. DGGE analysis can be used to detect sequence differences among the PCR products and therefore allows the identification of unique strains in a collection, which then may be selected for more detailed studies. Furthermore, interoperon sequence heterogeneities of $16 \mathrm{~S}$ rRNA genes within single genomes potentially leading to ambiguities in the sequence data can be detected (30). In this study, the amplification products that contained a single sequence, confirmed by DGGE, were sequenced directly. After purification by the QIAquick PCR purification kit (Diagen, Düsseldorf, Germany), PCR products were used as templates in sequencing reactions with the Applied Biosystems PRISM Dye Terminator Cycle Sequencing Ready reaction kit supplied with AmpliTaq DNA polymerase. Sequences of both DNA strands were determined by using the same primers as those used for amplification. Products of sequencing reactions were 


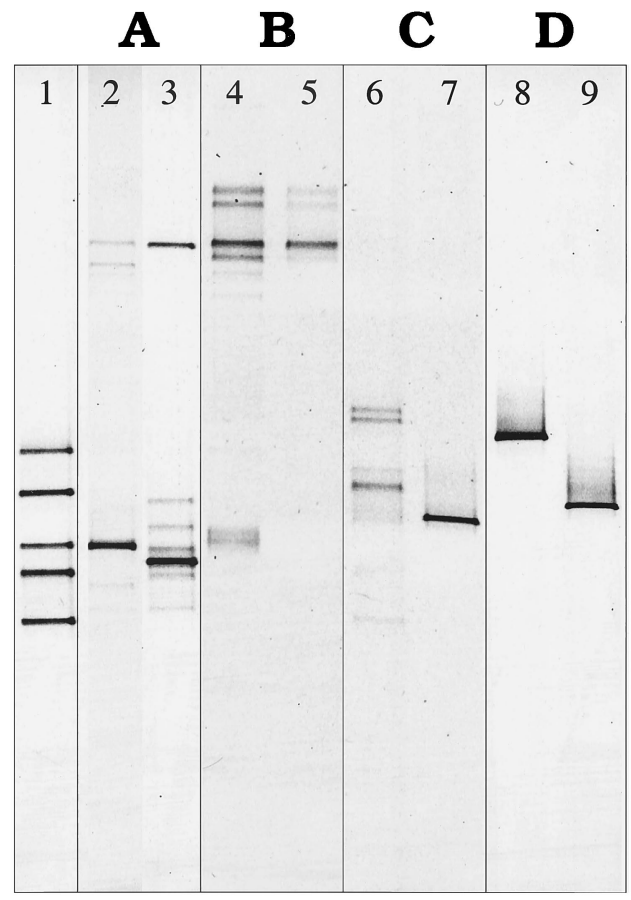

FIG. 1. Composite figure of ethidium bromide-stained DGGE separation patterns of PCR-amplified segments of 16S rRNA genes. A mixture of PCR products derived from five cyanobacterial strains was applied on each gel as a standard to allow gel-to-gel comparisons (lane 1, top to bottom: Scytonema strain B-77-Scy.jav., Synechococcus leopoliensis SAG 1402-1, Microcoleus chthonoplastes MPI-NDN-1, Geitlerinema strain PCC 9452 ["Microcoleus" strain $10 \mathrm{mfx}$ ], Cyanothece strain PCC 7418). Primers CYA359F and CYA781R were used for amplification. (A) PCR products derived from microbial mats P4 (lane 2) and NC20 (lane 3), which had been sampled from environments of different salinities (9 and 5 to 30\%, respectively). Primers CYA359F and CYA781R were used for amplification. (B) PCR products derived from marine plankton, which had been sampled from a seawater mesocosm after incubation for $65 \mathrm{~h}$ (lane 4 ) and $281 \mathrm{~h}$ (lane 5). Primers CYA359F and CYA781R were used for amplification. (C) PCR products derived from a nonaxenic culture of $G$. rupestris SAG 36.87. The use of primers complementary to gene stretches highly conserved among bacteria (40) yields amplification products heterogeneous in sequence (lane 6), whereas the primers CYA106F and CYA781R enable the selective amplification of the cyanobacterial gene segment (lane 7). (D) PCR products derived from photobionts from the lichens Collema cf. coccophorum (lane 8) and P. lingulata (lane 9). Primers CYA106F and CYA781R were used for amplification.

analyzed by using an Applied Biosystems 377 DNA sequencer. Many fragments were analyzed, yielding cyanobacterial sequences in all cases. Sequence data generated for the nonaxenic strains "Oscillatoria limnetica," Geitlerinema strain PCC 9452 ("Microcoleus" strain $10 \mathrm{mfx}$ ), and Gloeothece rupestris SAG 36.87 and for the plastids from Amphora delicatissima MPI 96P201 and Navicula salinicola MPI 96P205 were deposited in GenBank. Whereas the use of complete 16S rRNA gene sequences is recommended for reliable phylogeny reconstruction, information about shorter gene segments usually is sufficient for the identification of bacteria (38).

Symbiotic cyanobacteria in lichens. Cyanobacteria belonging to the morphologically defined genera Calothrix, Chroococcidiopsis, Chroococcus, Cyanosarcina, Dichothrix, Entophysalis, Gloeocapsa, Hyella, Hyphomorpha, Myxosarcina, Nostoc, Scytonema, and Stigonema are all found in lichens as primary or secondary phototrophic symbionts (8). However, with some exceptions, the identification of the cyanobacterial photobionts in intact lichen thalli is impossible, because their morphology is modified by interactions with the fungal hyphae and because only some stages of the life cycle may be present. Thus, culti- vation is a necessary, although not necessarily sufficient, requirement for positive identification (15). We applied our methodology for the selective amplification of 16S rRNA gene segments to whole thalli of the cyanobacterial lichens Collema cf. coccophorum and Peltula lingulata. After cleaning the thallus surface by flushing it with distilled water under a dissecting microscope, we transferred small pieces (approximately 2 $\left.\mathrm{mm}^{3}\right)$ to $10 \mu \mathrm{l}$ of TE buffer $(10 \mathrm{mM}$ Tris- $\mathrm{HCl}[\mathrm{pH} 8], 1 \mathrm{mM}$ EDTA) in 1.5-ml microcentrifuge tubes and gently ground them with a pipette tip to release the cyanobacterial cells into suspension. A DNA extraction step was not necessary, and the suspensions $(1 \mu \mathrm{l})$ could be used directly as templates for PCR. DGGE analysis of the PCR products obtained (Fig. 1D) showed that only one sequence was amplified from each lichen and that the sequences were different. These results are consistent with the expected identity of the cyanobionts in Collema cf. coccophorum (Nostoc sp.) and P. lingulata (Chroococcidiopsis $\mathrm{sp}$.). The combination of selective 16S rRNA gene amplification, DGGE, and sequence analysis should provide a cultivation-independent, powerful tool for the reliable identification of cyanobacterial symbionts at large.

Oxygenic phototrophs in complex microbial communities. Benthic microbial mats growing in evaporation ponds of the Exportadora de Sal saltworks in Guerrero Negro, Baja California Sur, Mexico, and marine plankton samples from a mesocosm study in the western Mediterranean were investigated. Mat core samples (diameter, $25 \mathrm{~mm}$ ) were frozen on-site, transported to the laboratory in liquid nitrogen, and stored at $-70^{\circ} \mathrm{C}$ until further use. Prior to the extraction of nucleic acids, the photosynthetically active layer, as determined by oxygen microelectrode measurements (reference 32 and data not shown), was aseptically cut from mat cores $(300 \mathrm{mg}$ ) and homogenized in a Dounce tissue homogenizer (Novodirect, Kehl, Germany). Cell lysis was performed as described above and controlled by light-microscopic observation. Mesocosm water samples containing $2 \times 10^{8}$ bacterial cells were filtered through Durapore GVWP 02500 filters (pore size, $0.22 \mu \mathrm{m}$; filter diameter, $25 \mathrm{~mm}$; Millipore). Nucleic acids were extracted from microorganisms retained on the filters by applying the protocol described by Teske et al. (40).

As shown in Fig. 1A and B, DGGE analysis of PCR amplification products visualizes the genetic diversity of cyanobacteria and plastids as reflected in 16S rRNA gene sequences. Similarities, differences, and successions in space and time of the composition of oxygenic phototrophic microbial communities can be observed by comparing different PCR products. More information can be obtained from these band patterns by sequence analysis of PCR products from single bands after elution from the gel and reamplification $(11,24,25)$. DNA bands may also be identified by hybridization analysis with suitable nucleic acid probes, if they are available (25). PCR products derived from cultivated strains may be assigned to bands of the complex pattern visible at the same height in the DGGE gel; although equal mobility of DNA molecules does not prove their sequence identity, this information can support comparisons of cultures and field samples. For example, a comparison of lanes 1 and 2 in Fig. 1 indicates that the most intense band in the pattern derived from the microbial mat P4 (lane 2) corresponds to the band derived from the cultured strain MPI-NDN-1 (lane 1). This result is consistent with the microscopic observation of filaments morphotypically corresponding to Microcoleus chthonoplastes (16), which dominate this mat.

Concluding remarks. In general, rRNA genes are considered to be more conserved in function and structure than protein-coding genes, and thus the genetic diversity measured 
might not sufficiently reflect the physiological diversity of the respective organisms $(14,42)$. On the other hand, sequence heterogeneities due to multiple copies of $r r n$ operons within single genomes of bacteria may complicate the interpretation of sequence data or DGGE band patterns, particularly when retrieved from natural microbial communities. The detection of slightly different $16 \mathrm{~S}$ rRNA gene sequences is not sufficient to prove the presence of different bacterial populations in an environmental sample (30). The rpoC1 gene, encoding the $\gamma$ subunit of RNA polymerase, has been described as an alternative target for analysis of cyanobacterial phylogeny (5) and community structure (31). However, the sequence data available for these genes are rather limited, whereas the determination of 16S rRNA gene sequences is a routine procedure in prokaryotic taxonomy today, resulting in large and steadily growing databases which improve the robustness of phylogeny reconstructions, identification results, and primer specificity evaluations. Other molecular biological approaches which have been described for the identification of cyanobacteria are applicable exclusively to axenic cultures. These include multiplex randomly amplified polymorphic DNA analysis (26) and the sequence analysis of internal transcribed spacer regions of ribosomal RNA operons (47). Some other approaches apply to only certain groups of cyanobacteria. The latter include the analysis of genes encoding phycocyanin (published primers were reported to yield no PCR products with some of the strains checked [27]) or nitrogenase (3) and the detection of a repetitive DNA sequence in toxin-producing heterocystous cyanobacteria (36). Partly reflecting the wide application of PCR in the field of microbial ecology, several potential pitfalls of this technique, such as the formation of chimera molecules (21) or the amplification of template molecules with differential efficiencies despite identical priming sites, have been described $(33,39)$. It should be noted that the primers used in microbial ecology are always designed on the basis of limited sets of data; future research might reveal sequences from target organisms which do not contain the signatures necessary for efficient amplification. However, the approach described here is a powerful tool for investigating the phylogenetic diversity of cyanobacteria and its ecological significance. This approach should prove especially useful for unraveling the connections between cyanobacterial populations observed in nature, molecular sequence data, and physiology.

Nucleotide sequence accession numbers. Accession numbers U96442 to U96446 were assigned to the $16 \mathrm{~S}$ rRNA gene sequences determined for Geitlerinema strain PCC 9452 ("Microcoleus" sp. strain $10 \mathrm{mfx}$ ), "O. limnetica," G. rupestris SAG 36.87, and the plastids from $A$. delicatissima MPI 96P201 and Navicula salinicola MPI 96P205.

The research described in this study was financially supported by the Max Planck Society and the Deutsche Forschungsgemeinschaft.

We thank B. Büdel for the herbarium sample of $P$. lingulata and the identification of the lichens; M. Hernández-Mariné and E. Clavero for the identification of the diatoms; Y. Cohen, P. K. Hayes, and H. Jannasch for the gifts of bacterial strains; and B. Cleven and H. Schäfer for critically reading the manuscript. We also thank Exportadora de Sal, S.A.D.C.V., Guerrero Negro, Baja California Sur, Mexico, for support in our field collections.

\section{REFERENCES}

1. Altschul, S. F., W. Gish, W. Miller, E. W. Myers, and D. J. Lipman. 1990. Basic local alignment search tool. J. Mol. Biol. 215:403-410.

2. Anagnostidis, K., and J. Komárek. 1985. Modern approach to the classification system of cyanophytes. 1. Introduction. Arch. Hydrobiol. Suppl. 71: 291-302.

3. Ben-Porath, J., and J. P. Zehr. 1994. Detection and characterization of cyanobacterial nifH genes. Appl. Environ. Microbiol. 60:880-887.
4. Benson, D. A., M. S. Boguski, D. J. Lipman, and J. Ostell. 1997. GenBank. Nucleic Acids Res. 25:1-6.

5. Bergsland, K. J., and R. Haselkorn. 1991. Evolutionary relationships among eubacteria, cyanobacteria, and chloroplasts-evidence from the $r p o C 1$ gene of Anabaena sp. strain PCC-7120. J. Bacteriol. 173:3446-3455.

6. Bhattacharya, D., and L. Medlin. 1995. The phylogeny of plastids: a review based on comparisons of small-subunit ribosomal RNA coding regions. J. Phycol. 31:489-498.

7. Brosius, J., T. Dull, D. D. Sleeter, and H. F. Noller. 1981. Gene organization and primary structure of a ribosomal RNA operon from Escherichia coli. J. Mol. Biol. 148:107-127.

8. Büdel, B. 1992. Taxonomy of lichenized procaryotic blue-green algae, p 301-324. In W. Reisser (ed.), Algae and symbioses: plants, animals, fungi, viruses, interactions explored. Biopress Ltd., Bristol, England.

9. Castenholz, R. W., and J. B. Waterbury. 1989. Oxygenic photosynthetic bacteria, group I. Cyanobacteria, p. 1710-1728. In J. T. Staley, M. P. Bryant, N. Pfennig, and J. G. Holt (ed.), Bergey's manual of systematic bacteriology. Williams \& Wilkins Co., Baltimore, Md.

10. Castenholz, R. W. 1992. Species usage, concept, and evolution in the cyanobacteria (blue-green algae). J. Phycol. 28:737-745

11. Ferris, M. J., G. Muyzer, and D. M. Ward. 1996. Denaturing gradient ge electrophoresis profiles of $16 \mathrm{~S}$ rRNA-defined populations inhabiting a hot spring microbial mat community. Appl. Environ. Microbiol. 62:340-346.

12. Ferris, M. J., A. L. Ruff-Roberts, E. D. Kopczynski, M. M. Bateson, and D. M. Ward. 1996. Enrichment culture and microscopy conceal diverse thermophilic Synechococcus populations in a single hot spring microbial mat habitat. Appl. Environ. Microbiol. 62:1045-1050.

13. Fitzsimons, A. G., and R. V. Smith. 1984. The isolation and growth of axenic cultures of planktonic blue-green algae. Br. Phycol. J. 19:156-162.

14. Fox, G. E., J. D. Wisotzkey, and P. Jurtshuk, Jr. 1992. How close is close: 16S rRNA sequence identity may not be sufficient to guarantee species identity. Int. J. Syst. Bacteriol. 42:166-170.

15. Friedl, T., and B. Büdel. 1996. Photobionts, p. 8-23. In T. H. Nash III (ed.), Lichen biology. Cambridge University Press, New York, N.Y.

16. Garcia-Pichel, F., L. Prufert-Bebout, and G. Muyzer. 1996. Phenotypic and phylogenetic analyses show Microcoleus chthonoplastes to be a cosmopolitan cyanobacterium. Appl. Environ. Microbiol. 62:3284-3291.

17. Geitler, L. 1932. Cyanophyceae. Akademische Verlagsgesellschaft, Leipzig, Germany. [Reprint, Johnson Reprint Co., New York, N.Y., 1971.]

18. Giovannoni, S. J. 1991. The polymerase chain reaction, p. 178-203. In E Stackebrandt and M. Goodfellow (ed.), Nucleic acid techniques in bacterial systematics. John Wiley and Sons, Chichester, England.

19. Lerman, L. S., S. G. Fischer, I. Hurley, K. Silverstein, and N. Lumelsky 1984. Sequence-determined DNA separations. Annu. Rev. Biophys. Bioeng. 13:399-423.

20. Lewin, R. A. 1989. Oxygenic photosynthetic bacteria, group II. Order Prochlorales, p. 1799-1806. In J. T. Staley, M. P. Bryant, N. Pfennig, and J. G. Holt (ed.), Bergey's manual of systematic bacteriology. Williams \& Wilkins Co., Baltimore, Md.

21. Liesack, W., H. Weyland, and E. Stackebrandt. 1991. Potential risks of gene amplification by PCR as determined by $16 \mathrm{~S}$ rDNA analysis of a mixedculture of strict barophilic bacteria. Microb. Ecol. 21:191-198.

22. Maidak, B. L., G. J. Olsen, N. Larsen, R. Overbeck, M. J. McCaughey, R. Overbeek, and C. R. Woese. 1997. The RDP (ribosomal database project) Nucleic Acids Res. 25:109-110.

23. Muyzer, G., E. C. de Waal, and A. G. Uitterlinden. 1993. Profiling of complex microbial populations by denaturing gradient gel electrophoresis analysis of polymerase chain reaction-amplified genes coding for 16S rRNA. Appl. Environ. Microbiol. 59:695-700.

24. Muyzer, G., A. Teske, C. O. Wirsen, and H. W. Jannasch. 1995. Phylogenetic relationships of Thiomicrospira species and their identification in deep-sea hydrothermal vent samples by denaturing gradient gel electrophoresis of 16S rDNA fragments. Arch. Microbiol. 164:165-172.

25. Muyzer, G., S. Hottenträger, A. Teske, and C. Wawer. 1996. Denaturing gradient gel electrophoresis of PCR-amplified 16S rDNA- a new molecular approach to analyse the genetic diversity of mixed microbial communities, $\mathrm{p}$. 3.4.4/1-23. In A. D. L. Akkermans, J. D. van Elsas, and F. J. de Bruijn (ed.) Molecular microbial ecology manual. Kluwer Academic Publishers, Dordrecht, The Netherlands.

26. Neilan, B. A. 1995. Identification and phylogenetic analysis of toxigenic cyanobacteria by multiplex randomly amplified polymorphic DNA PCR. Appl. Environ. Microbiol. 61:2286-2291.

27. Neilan, B. A., D. Jacobs, and A. E. Goodman. 1995. Genetic diversity an phylogeny of toxic cyanobacteria determined by DNA polymorphisms within the phycocyanin locus. Appl. Environ. Microbiol. 61:3875-3883.

28. Nelissen, B., Y. Van de Peer, A. Wilmotte, and R. de Wachter. 1995. An early origin of plastids within the cyanobacterial divergence is suggested by evolutionary trees based on complete $16 \mathrm{~S}$ rRNA sequences. Mol. Biol. Evol. 12:1166-1173.

29. Nelissen, B., R. de Baere, A. Wilmotte, and R. de Wachter. 1996. Phylogenetic relationships of non-axenic filamentous cyanobacterial strains based on 16S rRNA sequence analysis. J. Mol. Evol. 42:194-200. 
30. Nübel, U., B. Engelen, A. Felske, J. Snaidr, A. Wieshuber, R. I. Amann, W. Ludwig, and H. Backhaus. 1996. Sequence heterogeneities of genes encoding 16S rRNAs in Paenibacillus polymyxa detected by temperature gradient gel electrophoresis. J. Bacteriol. 178:5636-5643.

31. Palenik, B. 1994. Cyanobacterial community structure as seen from RNA polymerase gene sequence analysis. Appl. Environ. Microbiol. 60:3212-3219.

32. Revsbech, N. P., and B. B. Jørgensen. 1986. Microelectrodes: their use in microbial ecology. Adv. Microb. Ecol. 9:293-352.

33. Reysenbach, A.-L., L. J. Giver, G. S. Wickham, and N. R. Pace. 1992. Differential amplification of rRNA genes by polymerase chain reaction. Appl. Environ. Microbiol. 58:3417-3418.

34. Rippka, R., J. Deruelles, J. B. Waterbury, M. Herdman, and R. Y. Stanier. 1979. Generic assignments, strain histories, and properties of pure cultures of cyanobacteria. J. Gen. Microbiol. 111:1-61.

35. Romanowski, G., M. G. Lorenz, and W. Wackernagel. 1993. Use of polymerase chain reaction and electroporation of Escherichia coli to monitor the persistence of extracellular plasmid DNA introduced into natural soils. Appl. Environ. Microbiol. 59:3438-3446.

36. Rouhiainen, L., K. Sivonen, W. J. Buikema, and R. Haselkorn. 1995. Characterization of toxin-producing cyanobacteria by using an oligonucleotide probe containing a tandemly repeated heptamer. J. Bacteriol 177:60216026.

37. Sheffield, V. C., D. R. Cox, L. S. Lerman, and R. M. Myers. 1989. Attachment of a 40-base-pair $\mathrm{G}+\mathrm{C}$-rich sequence (GC-clamp) to genomic DNA fragments by the polymerase chain reaction results in improved detection of single-base changes. Proc. Natl. Acad. Sci. USA 86:232-236.

38. Stackebrandt, E., and F. A. Rainey. 1995. Partial and complete 16S rDNA sequences, their use in generation of 16S rDNA phylogenetic trees and their implications in molecular ecological studies, p. 3.1.1/1-17. In A. D. L. Akkermans, J. D. van Elsas, and F. J. de Bruijn (ed.), Molecular microbial ecology manual. Kluwer Academic Publishers, Dordrecht, The Netherlands.

39. Suzuki, M. T., and S. J. Giovannoni. 1996. Bias caused by template annealing in the amplification of mixtures of $16 \mathrm{~S}$ rRNA genes by PCR. Appl. Environ. Microbiol. 62:625-630.
40. Teske, A., C. Wawer, G. Muyzer, and N. B. Ramsing. 1996. Distribution of sulfate-reducing bacteria in a stratified fjord (Mariagerfjord, Denmark) as evaluated by most-probable-number counts and denaturing gradient ge electrophoresis of PCR-amplified ribosomal DNA fragments. Appl. Environ. Microbiol. 62:1405-1415.

41. Van de Peer, Y., G. Van der Auwera, and R. De Wachter. 1996. A quantitative map of nucleotide substitution rates in bacterial ribosomal subunit RNA. Nucleic Acids Res. 24:3381-3391.

42. Ward, D. M., M. J. Ferris, S. C. Nold, M. M. Bateson, E. D. Kopzynski, and A. L. Ruff-Roberts. 1994. Species diversity in hot spring microbial mats as revealed by both molecular and enrichment culture approaches-relationship between biodiversity and community structure. NATO ASI Ser. G Ecol. Sci. 35:33-44.

43. Ward, D. M., C. M. Santegoeds, S. C. Nold, N. B. Ramsing, M. J. Ferris, and M. M. Bateson. 1997. Biodiversity within hot spring microbial mat communities: molecular monitoring of enrichment cultures. Antonie van Leeuwenhoek 71:143-150.

44. Weller, R., J. Walsh Weller, and D. M. Ward. 1991. 16S rRNA sequences of uncultivated hot spring cyanobacterial mat inhabitants retrieved as randomly primed cDNA. Appl. Environ. Microbiol. 57:1146-1151.

45. Wilmotte, A., and S. Golubic. 1991. Morphological and genetic criteria in the taxonomy of cyanophyta/cyanobacteria. Arch. Hydrobiol. Suppl. 92:1-24.

46. Wilmotte, A., S. Turner, Y. Van de Peer, and N. R. Pace. 1992. Taxonomic study of marine oscillatoriacean strains (cyanobacteria) with narrow trichomes. II. Nucleotide sequence analysis of the $16 \mathrm{~S}$ ribosomal RNA. J. Phycol. 28:828-838.

47. Wilmotte, A. 1994. Molecular evolution and taxonomy of the cyanobacteria p. 1-25. In D. A. Bryant (ed.), The molecular biology of cyanobacteria Kluwer Academic Publishers, Dordrecht, The Netherlands.

48. Wilson, K. 1990. Preparation of genomic DNA from bacteria, p. 2.4.1-2.4.2. In F. M. Ausubel, R. Brent, R. E. Kingston, D. D. Moore, J. G. Seidman, J. A. Smith, and K. Struhl (ed.), Current protocols in molecular biology. John Wiley \& Sons, Inc., New York. 